\title{
New Problems and Countermeasures of Research Tourism-A Case Study of Teenager's Tourism Education
}

\author{
Xiaoliang Chen ${ }^{1, *}$ \\ ${ }^{1}$ Tourism and Urban Management College, Tourist Development Research Center, Jiangxi University of Finance and \\ Economics, Nanchang City, Jiangxi, 330032, China. \\ *Corresponding author. Email: jxchenxiaoliang@163.com
}

\begin{abstract}
Research tourism in the Post-Pandemic Era is a new educational model which combines the conventional model of education economy growth and the in-depth development of tourism industry with modern technology. Against the backdrop that the coronavirus outbreak is easing at home and abroad, it has been faced with new development status along with many novel problems. Concern and reflection on those would be of a certain theoretical and practical significance for the new construction of the national ideological and political education, the development and innovation of tourism education, and the update of tourism teaching philosophy.
\end{abstract}

Keywords: Teenagers' tourism education, Research tourism, Countermeasures

\section{INTRODUCTION}

Tourism education lies in the development trend of enriching the content of higher education. It is an innovative education model with the extension of quality education in particular scenes.

Research Tourism is a kind of tourism education activity organized by teaching and research institutes or tourism enterprises, which takes young students as the subjects of education and learning and is under a certain education and learning theme for a specific teaching and research purpose. Specifically, teenagers' research tourism serves as an adequate teaching means that provides students with life experience, helps them broaden their horizons and increases their knowledge. Adolescent research tourism in foreign countries is flourishing and has become a hot new educational product. This is especially the case in the teaching of Europe, America, South Korea and Japan, where it has become an important and inseparable part of daily learning. Some countries even take research and education tourism as a mandatory teaching session, and there is also scientific and reasonable standardization of specification in teaching methods and teaching hours.

In contrast, China's research tourism still has significant weaknesses in the promotion and popularization of educational content, the indoctrination and cultivation of teaching ideas, the reform and innovation of teaching methods, etc. due to the differences of regional economic development and the other comprehensive problems. Despite the fact that preliminary work has been done in some areas, on the whole, research tourism is still in the initial period riddled with challenges. Currently, China has carried out the pilot work of research tourism in some areas. The government, enterprises and educational institutions have cooperated with each other to vigorously support and promote the development of research tourism in some regions, and achieved good economic, social and cultural effects. In the short term, research tourism has not been popularized nationwide, a reasonable and scientific curriculum system has not been established in teaching, and an effective feedback evaluation mechanism has not been established in teaching assessment. Nevertheless, it has become a new teaching method in the Post-Pandemic Era, and a new form of sustainable development in line with the current tourism market and the future development vision of education industry [1].

\section{EMERGENCE OF PROBLEMS}

As China's teenager tourism education is still in the initial stage of development, there are still certain problems in the tourism market.

For instance, the supervision of the education sector at the national level needs to be further strengthened, and the standardized and procedural steps of the tourism education market need to be improved. For another example, the innovative, artistic design of tourism education curriculum including teaching through lively activities is to be deeply developed. Teenagers' research tourism is still in the early stage of development, with single products and incomplete planning. The common ones mainly involve professional experience and visits to prestigious schools, which lack novelty and therefore is difficult to improve the quality of students and give full play to the role of research tourism comprehensively and effectively. Paying more attention to tourism than learning is also a long-standing problem in the development of research tourism. Problems such as the 
low-quality content of research and learning, the lack of in-depth explanation and the poor learning effect of participants have greatly undermined parents' confidence in research and learning education tourism. In addition, it is required that research tourism should continue to improve students' safety education. Owing to the large number of students participating in tourism, most of whom are at a young age with poor self-protection awareness, there is a greater possibility of potential safety hazards. At present, research tourism has been promoted nationwide, but the relevant market norms and practice methods have not been fully determined. Overall, research tourism has not established a standard system across the country. The participants include schools, educational institutions, tourism enterprises and agents, while most research and education tourism are in a state of no management and no regulation.

It can be inferred that the traditional education mode has been entrenched and can not meet the needs of the market environment in the Post-Pandemic Era. The pause button pressed by COVID-19 allows the overheated tourism education in some areas to have a period of calm reflection, to get rid of impetuosity and blind movement, so as to return to rationality and science and to the essence of education. All parties involved in research tourism should make full use of this period of time to conduct a comprehensive and profound reflection and summary of the work carried out in the past, find out the shortcomings, refine the successful experience and achievements. On top of that, those involved should constantly cultivate their internal skills, train proper talents, improve the existing research courses and routes, and develop new ones.

\section{NEW CHALLENGES AND NEW SITUATIONS}

In the Post-Pandemic Era, research tourism is facing various challenges and new situations.

\subsection{The willingness of tourists in the tourism education market is weakened.}

Since the novel coronavirus pneumonia is highly infectious, the government departments strictly prohibit the gathering of people. This leads to the fact that the leadership of the education administration department and the school officials are unwilling and dare not to organize their students to carry out the research tourism activities. Likewise, parents would remain in a state of anxiety because of constant worries. In the Post-Pandemic Era, the state's pandemic prevention and control towards school students will be much stricter than other types of tourists, and research education activities tend to be restricted or even stopped. In the post pandemic era, the experience mode and education mode of research tourism will change with the degree of destination control, so the diversity of research education content will be reduced, and the effect of it will be influenced as well.

\subsection{It is more difficult to operate and manage the education base and tourism enterprises.}

In the first place, the current research tourism market is generally haphazard in that the development and operation, planning and consultation, route design and service awareness are not standardized, and there is no scientific and standardized industry standard. Furthermore, the pandemic has increased people's panic about gathering activities, coupled with the stricter requirements for safety in the research tourism industry, resulting in a significant reduction in the number of customers. Last but not least, the monthly employee salary expenditure, office rent payment and daily operation cost have increased, which makes it harder for the research base and enterprises to operate.

In a considerable number of tourism enterprises, both management and grass-roots staff are confronted with the problems of future development and transformation, even bankruptcy and unemployment, which greatly affects the cohesion and centripetal force of enterprises.

\subsection{The safety of teenagers' research tourism is also a big concern}

Research tourism can meet the requirements of teenagers in perceiving new things, cultivating sentiment and releasing personal pressure. It is very beneficial to the growth of teenagers. However, with the increase of research tourism activities, risks regarding traffic conditions, food safety and tourism consumption fraud increased, and the safety problems followed. Security is the primary and key bottleneck. Safety is an impassable red line for the development of research tourism market, and it is also a restrictive factor for the comprehensive and healthy growth of research tourism. Under the background of pandemic normalization, how to ensure safety will be of top priority.

\section{INNOVATION AND DEVELOPMENT}

Research education needs innovation in the Post-Pandemic Era.

\subsection{The teaching concept of research education should be innovated}

For one thing, research tourism should be an interactive experience. The life value of tourism products lies in the idea that tourists are not just onlookers, but participants, witnesses and even product decision-makers. They can 
deeply participate in it, fully interact, and integrate into multiple processes of research tourism experience such as performances, festival activities and production work, so as to form an experience trend of participating, acquiring and sharing. For another, research tourism should bring economic and social benefits. "Traveling with textbooks" is one possible means to break the school wall and create the second classroom for teenagers. How to organically combine research activities with school courses and let students integrate into the natural landscape and humanistic society is the key for students to quickly expanding their horizons, perceiving nature, stimulating interest and obtaining inspiration. Therefore, conducting research tourism properly can not only achieve educational fun, but also gain a head start in the future market by shortening cognitive distance and strengthening empathic influence through research tourism.

\subsection{The teaching project, content and process design of research tourism should be innovated}

Affected by the pandemic, the research tourism is only limited to the campus, and it is nearly impossible to extend the school research and education tourism to social research and learning, which is lacking in innovation.

In general, it is necessary to expand the categories of research tourism. Because of the pandemic, people have a deeper understanding of sanitation, life, health, animals, family affection and diet, and the enterprises can increase the research content in this regard. Specifically, this is reflected in the innovation of curriculum development and construction. Curriculum is the core of teaching activities. If there is no high-quality curriculum in research tourism, it is impossible to successfully achieve the intended educational objectives. Until now, the development and construction of research curriculum is still in spontaneous disorder without planning as a whole, which leads directly to uneven quality of research schooling curriculum. This is also a bottleneck of research tourism.

Therefore, in the development and construction of research tourism curriculum, it needs professional institutions to make overall planning and incorporate experts, front-line teachers, research bases, research institutions and other relevant professionals to jointly develop curriculum resources and improve the regional curriculum system.

\subsection{The teaching environment should be innovated[2]}

In 2018, the Ministry of Education issued the Opinions on Promoting Research Travel in Primary and Secondary Schools. In 2019, the General Office of the State Council also clearly proposed to "develop cultural experience tourism, leisure tourism, research tourism and other business products" in the opinions on further stimulating cultural tourism consumption.
Unfortunately, the world pandemic broke out at the end of 2019, and tourism markets stopped developing almost entirely. Now, we are in the "Post- pandemic era", which is a time for the recovery of the whole tourism industry and a time for the restart of research tourism.

This requires giving full play to the characteristics of research tourism as well as cross-border cooperation and integration, breaking the traditional mode of being stubborn and self-righteous and restricting activities to a designated area, and striving to break through and out of the fixed circle. Research tourism should be transformed freely in resource integration and cross-border innovation with the effort of integrating and innovating regional characteristic cultural resources to break the dimensional wall and physical attributes. By making the operation methods updated iteratively, and the operation patterns emerge one after another, the innovation of tourism elements is promoted more effectively, and the research tourism is encouraged to take the road of high-quality and sustainable development.

This requires the creation of online research. During the cold winter of the pandemic, many industries have been greatly impacted, but some online apps have ushered in new development opportunities and even tremendous growth. Tourism government departments also advocate online operation. So, the tourism market turns to produce audio and video products, and even develop new technology products, such as TikTok, to be applied in online research class, which also represents the general trend of the future market. Both schools and research institutions should give active response, innovate the way of research tourism, make use of rich resources online, develop courses online, cooperate with schools and carry out research tourism activities online[3].

\subsection{The form of education display should be innovated}

In practice, authorities may penetrate and identify teenagers' leisure preferences with particular scenes-theme spaces such as China-chic block, animation town, internet-famous sites, amusement park, etc., and introduce film and TV drama shooting scenes in the scenic spot, recreate virtual worlds and fictional scenes such as animation and games, and present them in real world scenic spots, so as to restore the history and life scene, bring the history, culture and memory to life, and strive to achieve the scene of the content of research tourism products.

Local authorities can also take "science and technology plus research tourism" as the integration and innovation propeller to enrich the tour experience, provide accurate services and fully meet the personalized needs of teenagers. The content experience and consumption of virtual platforms such as cloud performance, cloud exhibition, cloud live streaming, cloud exposition, cloud classroom and cloud dinner can be realized online, while the immersive restaurants, performance and art exhibitions 
can be created offline. Through multi-level, multi-dimensional and multi series technological means, we can form online and offline content innovation and experience innovation.

In the Post-Pandemic Era, the tourism industry cannot carry out research and learning activities offline, let alone those on a large scale. Therefore, the research tourism industry should develop online-projects and launch cloud tourism projects similar to the cherry appreciation of Wuhan University.

For another example, enterprises can utilize VR technology to develop online courses similar to MOOC with their cooperative research schools for primary and secondary school students. Live streaming of activities online also moves the original offline activities and routes online, and some provide customers with VR glasses and other high-end service products.

In addition, we can also combine the psychological characteristics of teenagers and give play to their strong sports stickiness. The normalization of national fitness has made sports products a necessity for tourism experience. The scenic spot can provide a wide range of sports facilities and organize experience events, which greatly improves the participation and stimulation of the scenic spot. It is also an effective way for teenagers to enter, explore and love nature while strengthening their physique, releasing pressure and surpassing themselves, so they can truly enjoy the happiness of life.

\subsection{It is required to strengthen the construction of teaching staffs and give full play to the incentive measures[4]}

As the number of research tourism customers decreased during the pandemic, most employees of the enterprise group seemed under-occupied. As a result, we should take advantage of the hiatus of research tourism to save against a rainy day, organize enterprise employees to learn the business knowledge of research tourism, encourage employees to obtain relevant certificates, enhance team quality and ability, improve reception service processes and standards, and improve the overall service level.

At present, there is an extreme shortage of relevant research tourism professionals, including research tutors. The quality of personnel engaged in research tourism in the market is uneven. Some are engaged in the travel industry, some are engaged in the education, guidance and training industry, and many have not much knowledge of research and learning, and their engagement in research tourism is just superficial.

In terms of talent training in the future, it is necessary to strengthen the planning and construction of talent training system related to research tourism, and make the best of expertise of normal universities in training professionals. Teaching and research and relevant departments also need to strengthen the training of teachers and existing employees of research institutions involved, with the adoption of the method of multi-channel joint training to realize the full potential and function of talent echelon.

Simultaneously, tourism management departments and tourism enterprises need to take the lead to regain confidence, inspire employees, collect big data, predict future tourism development trends, enhance enterprise cohesion and centripetal force, strengthen the morale of tourism operation team, and pursue the improvement of "tourism plus education" professional quality.

\section{CONCLUSION}

The smooth development of research education is inseparable from various guarantee measures.

\subsection{Government needs to strengthen supervision, optimize the management mechanism of research tourism, and improve the security mechanism}

As teenagers experience tourism, the safety guarantee mechanism is indispensable. The governing education authorities can set up a special leading group for teenagers' travel safety, coordinate the guidance of research tourism safety, and formulate an emergency plan for tourism incidents. Meanwhile, it is also necessary to conduct qualification review and quality assessment for travel organizations or service groups. Schools shall conduct risk assessment on the design of travel routes and activities, establish emergency plans, and give safety warnings on possible safety risks and precautions in the process of research tourism.

In terms of security guidance, this requires certain government departments to further standardize the market and establish good order. Scenic spots and travel agencies should formulate early warning plans, negotiate with insurance companies to launch research tourism insurance, and guide all parties to cooperate and share safety responsibilities to ensure safe travel.

\subsection{It demands the continuous improvement of market mechanism and the laws and regulations on market segments}

According to the school's teaching material outline and teaching plan, the research and learning market is divided into several research and learning types such as popular science, natural viewing, experience investigation, inspirational development, and culture and recreation.

What is also needed is to standardize the market, prevent the excessive industrialization of tourism education, and pay attention to the importance of practice. The government should actively participate in or guide professional institutions to formulate scientific and standardized industry standards and regulate relevant 
institutions. Therefore, the improvement of project development and operation, planning and consultation, route design and other relevant operation standards is essential for the sustainable and healthy upgrade of research tourism.

\subsection{We must innovate outdated form for educational products and set good role models [5]}

Due to the impact of the pandemic, tourism has become a disaster area, and tourism education has also been significantly impacted. Although the tourism industry would probably show a retaliatory rebound after the pandemic, people will also be left with a potential psychology of fear of gathering activities in the short term, which will have a negative impact on research tourism.

As a result of the reduction of tourism education products, their quality will also decline due to the shrinkage of the market. In the end, there is no good example and role model for teenagers' research tourism, and the pandemic amplifies the defects of these informal research tourism. The Post-Pandemic Era has greatly compressed the traditional research space, i.e., it is necessary to avoid the forbidden or sensitive words such as "large scale", "gathering" and "outdoor". Hence, it is urgent to create a new way of education.

Moreover, tourists can visit some important former sites of pandemic prevention and control through the online platform to understand the specific situation back then, know the danger of the pandemic and how we should make personal efforts in the Post-Pandemic Era to avoid the occurrence of similar events. There are also several ways to improve the biomedical understanding level of teenagers through the popular science education on biomedicine such as viruses, as an old saying goes, "Know the enemy and know yourself, and you can fight a hundred battles with no danger of defeat". Deepening the understanding of the importance of pandemic prevention and control and knowing how to better prevent it are of both educational and practical significance[6].

\subsection{The subsidy for tourism education should be flexible and the resources should be allocated reasonably}

At present, China's government departments have already issued and will continue to issue policies and guidelines to support the further integration of production, education and research tourism, and provide support from the aspects of development concept, policy, capital, personnel, education, transportation, tourism and supervision system, which to a great extent provides a guarantee for the orderly and in-depth development of teenagers' tourism education. At the same time, the use of corresponding norms in research tourism has already greatly facilitated the standardization of its market and the efficiency of learning education. Therefore, in promoting the development of teenagers' research tourism, we should pay attention to the implementation of its related policies.

\section{ACKNOWLEDGMENT}

This paper is a 2009-year school-level youth project of Jiangxi University of Finance and Economics, "Research on Policy support of Red Tourism in southern Jiangxi province" (Code: 04662015). Phased results. Members: Xiaoliang Chen, Haisheng Hu, Jigang Tang, Fengjun Tian and Zhonglie Wang.

\section{REFERENCES}

[1] R.E. Freeman, Strategic Management: A Stakeholder Approach, Boston, MA: Pitman, 1984.

[2] He Kekang, "New Development of Educational Technology from a Perspective of Blending Learning" [J]. China: Journal of National Academy of Education Administration, vol. 9, 2005, p.47. (In Chinese)

[3] Jiankang Dong, Yan Han. Roles and Positioning of Various Subjects in Collaborative Innovation System [J]. Science and technology of Chinese universities, 2013(6), pp. 52-54. (In Chinese)

[4] Eryong Xue, Jian Li. "Creating a High-Quality Education Policy System", Springer Science and Business Media LLC, 2021.

[5] Zongkai Yang. Promoting Educational Modernization with Informatization: The Historical Responsibility of Educational Technology[J]. E-Education Research, 2018, (1), pp.5-11. (In Chinese)

[6] Li Songlin. Four Practice Points of Deep Teaching [J]. Educational Theory and Practice, 2014 (31), p.54. (In Chinese) 